\title{
The Development and Effectiveness of Motion Graphic Animation Videos to Improve Primary School Students' Sciences Learning Outcomes
}

\author{
Muhammad Hanif \\ Universitas Pendidikan Indonesia Serang Campus,Indonesia, muhammadhanif@upi.edu
}

This research aims to investigate the development and effectiveness of motion graphic video media for Primary Schools students in learning Natural Sciences subject. This exploratory sequential mix method study employs combination of descriptive qualitative method to define the current situation and product development process and the experimental method involving 27 fifth grade students in each control and experimental groups. This research was conducted in two different selected primary schools. The researcher uses in-depth interview and observations methods for the qualitative studies, and tests to measure the effectiveness of motion graphics media developed. In the qualitative stage, this study found that there is a need to develop an interactive audio visual media. The result of t-test showed that there were significant differences in terms of cognitive learning outcome between control and experimental group. Therefore, the interactive motion graphic video media developed is feasible and effectively proven to enhance the students' science learning achievement of the fifth grade of primary school level.

Keywords: motion graphic, learning media video, science subject, primary school, graphic animation

\section{INTRODUCTION}

Technology is now progressing forward rapidly. Various everyday human activities can now take the advantage of technology and began to influences extensively all social life aspects. Nowadays, functioning Internet, social media, and proliferation of information become essential parts of human life (Kayimbaşioğlu, Oktekin, \& Haci, 2016). The emerging technology is having a massive impact on how people live, learn, and interact. In addition, people are now easier to obtain information because real-time accessed of the information sources. Hence, it can be reckoned that technology will become an necessity in the future. Technologies expected to enter mainstream use in the first horizon of one year or less. It will be one of the primary human necessities in helping and increasing the human activities efficiency (Bagatarhan \& Siyez, 2017), rather than a

Citation: Hanif, M. (2020). The Development and Effectiveness of Motion Graphic Animation Videos to Improve Primary School Students' Sciences Learning Outcomes. International Journal of Instruction, 13(4), 247-266. https://doi.org/10.29333/iji.2020.13416a 
tertiary item. People live in a technologized society and are placed in the situation of the technologization. All aspects of future life, including education, will employ the integration of technology (Ignatyeva, 2015).

Modern technology addiction has begun to expand in all scope of human activities including education (Hlasna, Klimova, \& Poulova, 2017). Educators employ ICT to enhance their efficacy and quality of work. The current pedagogical literature pays considerable attention to the massive development of education technologization process. Those conditions have resulted in shifting the teachers' role, where currently they can no longer perform as the only information source for students' learning activities. The technology in education made teacher to perform the learning facilitator, pedagogue-manager and training director function, not information translator. The education system has an essential part in reaching the national development by empowering acquisition of knowledge (Kayimbaşioğlu, Oktekin, \& Haci, 2016). Education system aims to prepare generation for their living time by acquiring knowledge, mastering certain skills and forming student attitudes (Gurbuzturk, 2018). By education, the people will acquire the living tools to survive the individuals and communities' welfare.

In the modern learning paradigm, students' position is the center of learning. Teachers function to call students' learning interest, facilitate learners to discover and develop their motivation to learn, and to meet learners' satisfaction from the classroom lesson (Yakovleva \& Goltsova, 2016). The domination of teachers' role in the old-fashioned paradigm neglected students' involvement in the learning activity (Adilah, 2017). Thus, knowledge is trained, constructed by, and transferred to students who actively search. Since the primary school students are in phase of acquisition, the students' learning situation should be designed with interesting, interactive and meaningful activity. Therefore, the environment should be designed to gain their motivation to learn, the activity let them to work in team, and the contents of the program should reflect, and is set based on students' basic knowledge (Ucus, 2015).

In line with the modern learning paradigm, selected student activity and instructional media strongly determined the success of learning activities in primary schools. In the modern era, children naturally grow with high level of information access (Huda, et al., 2017) so teachers should shift their role as facilitator rather than information source. Consequently, information and communication technology has the possibility to enhance teaching and learning (Gellerstedt, Babaheidari, \& Svensson, 2018). The existence of computers and internet makes it an ideal tool for potentiating various implementations in the context of learning. In many countries, currently there is a changing paradigm to more interesting, interactive, experiential, and meaningful learning methods in education (Anikina \& Yakimenko, 2015). Educational practitioners need an ability to apply the modern media available and adopt Information and Communication Technology in an appropriate pedagogical manner (Gellerstedt, Babaheidari, \& Svensson, 2018).

Information and Communication Technologies are gradually changing the way knowledge is conceived and delivered (Assar, 2015). However, teachers have been expected to master and utilize optimally (Shaban \& Egbert, 2018). Unfortunately, from 
primary to the upper class (high school), teachers often apply conservative methods and learning media to present the knowledge. As results of a preliminary observation in one of the 5th grade primary schools, researcher observed that the science learning material was presented by making theoretical and logical examples and sticking to the textbooks (Pricahyo, Akhyar, \& Suharno, 2018) and using still picture drawn by the teacher on the whiteboard. Those situations may not optimize student learning achievement (Asrowi, Hadaya, \& Hanif, 2019). Moreover, teachers tended to use lecturing methods serving in the students' verbal knowledge of natural science and rarely presented concrete phenomena or media related to the studied materials. Generally, most students experience misinterpretations. They freely fantasize and try to visualize the theory given based on their own limited basic knowledge. This will cause problems when not anticipated correctly. Students will acquire and interpret material without visualization and confirmation whether it is true or not. In addition, teachers are lack of awareness on modern learning media utilization. Utilization of learning media tool is still rarely used. Although there is suitable supporting learning media facilities provided in school, teachers have not yet used the instructional media tools available in schools optimally. In fact, to integrate technology effectively, a professional competency development, such as adequate training can help teachers to employ the utilization and improve technological innovation in their professional life (Shaban \& Egbert, 2018). There are many challenges factors made teachers have not been able to take advantage of rapid technological development opportunities such as limited skills in technology operations and the absence of rules to use technology as a learning media.

Science learning is a process to learn about learners themselves and their surroundings. It deals with not only a collection of facts and concepts of natural phenomena, but also about how to work and think scientifically. To teach science in lower level of students is challenging. To bring a complex conceptual knowledge of real natural phenomena in classroom, teachers should facilitate students to develop the students' ability to reason logically and abstractly (Syawaludin, Gunarhadi, \& Rintayati, 2019). Technology-based learning media utilization could be solution to the limitations of visualization and bridging and students' abstract reasoning.

Based on several problems above, the present study tries to examine how to solve the problems faced as a result of teacher-centered learning by providing innovative learning media. The researcher proposes to develop interactive motion graphic animated videos as learning media to explain the science subject matter. Instructional animation video is selected to develop because most students show their interest in watch cartoons and animations. In addition, video animation also prevents students from getting bored, as they can present a pleasant, relaxed and humorous learning atmosphere, and still accommodate the main aspects learning material elements. Motion graphic is a sequentially manipulated image becomes a look like moving animation. Combined with audio, motion graphic can create the illusion of motion operated using animation technology.

The above statement is in line with the results of study conducted by Khalid, Meerah, \& Halim (2010) which put forward the research on cartoon-based learning. They examined 
the Malaysian physics teachers' views on the using cartoon in physics learning. Their study found that students have a positive perception on the use cartoons in classroom learning. The use of cartoon video can build a positive environment by stimulating students' imagination and creativity. By students' imagination and creativity, students were able to construct their own knowledge and master the conceptual material being delivered. The classroom learning process by using cartoons can be carried out in various active learning circumstances, such as discussion environment, team work and other students' active participation. By supporting active learning situations, the studentcentered learning class will be created and potentially increase learning outcome (Hapsari, Hanif, Gunarhadi, \& Roemintoyo, 2019).

In addition, Akamca, Ellez, \& Hamurcu (2009) also investigated the use of video on helping students to improve the science learning outcomes. They proposed cartoon video as alternative solution to enhance students' understanding, trigger classroom interaction and prevent students' miscomprehensions about scientific phenomena. This study indicates a positive effect of using cartoon media on improving students' science learning outcome. Cartoon videos effectively stimulate students to socially interact and give concept visualization.

Based on some of previous research above, it is legitimated that the selection of cartoons or other animation video, such as motion graphic is an alternative solution toward classroom learning problems found in the preliminary observation. So, the researcher hypotheses that motion graphic video media is effective to increase the natural science learning outcomes of primary school students.

\section{METHOD}

\section{Research Type}

This study uses an exploratory sequential mixed method research design (Creswell \& Clark, 2011). The exploratory sequential approach was selected to investigate the current situation and need for developmental process qualitatively and to examine the effectiveness of motion graphic video media for science learning in primary school quantitatively in sequential process. This research is guided by three research questions:

Q1: How is the present natural sciences learning process carried out in the classroom?

Q2: Is motion graphic video effective to enhance science learning outcome in primary school?

The purposes of this research are to find out the need analysis on learning media, describe the development process and determine the motion graphic media effectiveness to enhance science learning achievement of primary school students. Question Q1 and Q2 are sequentially carried out using qualitative to answer the need of development. Thus quantitative analysis was conducted to examine the motion graphic animation media effectiveness. This research is part of developmental research which previously published (Hapsari et al., 2019) with concern on the effectiveness aspect. 


\section{Research Population and Samples}

This research involved two state primary schools in Sukoharjo City, Indonesia. The primary school is taken into this population since there are science learning problems found in the initial observation. The fifth grade is the critical grade before facing the National Examination in sixth grade for determining graduation from the Primary School level. In this level pupils are expected to master complex conceptual material, abstract reasoning and understand some foreign terms in Science subject. The participants is a total 54 students of two classes from two different schools. Purposive sampling is used to select samples with similar characteristics based on research objectives then divided into control and experimental groups. Four science teachers and two principals from those two primary schools are also involved as participants in qualitative stage.

In the qualitative stages, researcher observed the classroom learning situation to formulate the need for learning media development. The observation is supported by confirmation data from interview with teachers and principals. The result of need analysis is taken for developmental basis of animation video learning media. The media develop the validated by content and media expert and prospective user to measure the feasibility. The researcher divided the samples into control and experimental group before conducted a treatment. The experimental group treated by using motion graphic animation video media. Thus, the control group used still picture and 2D image media as comparation rather than motion graphic video animation media in Natural Sciences learning.

\section{Instrument of Data Collecting}

In the qualitative stage of the study, the data collection techniques used are field observations, interviews, and documentation (Creswell \& Clark, 2011).

Observation is taken by noticing the classroom learning practice executed by the teacher in two meetings. It collects information of the current learning methods and media used in the classroom and interaction of student during learning process. Whereas interviews are organized to get information about constraints in carrying out learning practices faced by the teacher and teachers' offered solutions in solving the challenges arise in learning practices. Student behavior during classroom learning is also observed to define the students' characteristics. The researcher used unstructured open question to interview four primary classroom teachers from those two classes to collect the information about the need of learning media. The interview is guided by limitation of the learning media used, the reason of using selected media and supportive atmosphere of school in encouraging teacher use technology in learning. Documentation is executed by collecting learning report, lesson plan and quality assurance system documents. They are useful for resuming information data about the students' learning achievements obtained in observed classroom learning as well as the facilities and infrastructure provided by school.

In the developmental stages, 5-scale Likert questionnaire is also used for gaining data of the experts and user validation on media developed. The media developed is validated 
in aspects of media purposes, content quality, visual and language appropriateness, subject matter, presentation and ease of use. Thus, for the experimental stage, a cognitive test before and after the use of motion graphic animation video is used to collect the data. 30 multiple choice questions instruments in science subject is compiled and used by the researcher to measure the achievement of science learning. Furthermore, the instrument is passed the validity test (Pearson's product moment) by gaining value of 0.66 and concluded as reliable instrument by gaining the $r$ table of 0.3550 with a significance of 0.05 .

\section{Data analysis}

The qualitative data in the need analysis and developmental stage is presented in descriptive way. The qualitative data is analyzed by data reduction, display and conclusion drawing or clarification. Data reduction is done by strictly selecting summaries or descriptions of the findings of observations, interviews and documentation and then classifying them into specific and general patterns according to the required categories based on research objectives.

The data in experimental stage is analyzed by using SPSS 2.0 on the t-test analysis. Before analyzing data collected, the data have to meet two prerequisite tests of normality and homogeneity. Normality test is to examine whether the data of the two groups are normally distributed. Shapiro-Wilk test is used with significance criteria the value of 0.05 to explain the normality of data distribution.

Table 1

Result of Data Normality Test

\begin{tabular}{|c|c|c|c|}
\hline Item & Group & p sig & Analysis \\
\hline \multirow{2}{*}{ Post-test } & Control & 0.387 & \multirow{4}{*}{$\begin{array}{l}\text { Sig. } \text { (2-tailed) value }>0.05 \\
\text { (Normally distributed) }\end{array}$} \\
\hline & Experiment & 0.248 & \\
\hline \multirow{2}{*}{ Pre-test } & Control & 0.473 & \\
\hline & Experiment & 0.523 & \\
\hline
\end{tabular}

The table 1 above showed that, $\mathrm{n}$ the post-test, experimental group scored a significance value of 0.248 , while the control group gained 0.387 . These output explained that the post-test data had normal distribution ( $\mathrm{p} \mathrm{Sig}>0.05$ ). In pre-test, the significance value of the experimental group is 0.523 while in the control group obtained 0.473. In conclusion, the students' science learning achievement test for both the control and the experimental group in both post-test and pre-test had normal data distribution.

Besides to test the data normality, the homogeneity test is also executed before analysis. The homogeneity test intends to examine whether the data variant from two groups is homogeneous (based on Mean > 0.05).. Homogeneity of the two group data variances are prerequisites for producing accurate calculation of the t-test. 
Table 2

Results of Homogeneity Test

\begin{tabular}{|c|c|c|c|}
\hline Item & Group & Based on Mean & Analysis \\
\hline \multirow[t]{2}{*}{ Post-test } & Control & & \multirow{3}{*}{$\begin{array}{l}\text { Based on Mean value }>0,05 \\
\text { (Homogenous) }\end{array}$} \\
\hline & Experiment & 0.902 & \\
\hline Pre-test & Control & 0.268 & \\
\hline
\end{tabular}

Table 2 above showed that the data homogeneity test of the post-test group obtained the value of 0.902 . It indicates the data of the post-test of two groups is homogeneous The same result is also shown in pre-test data of the two groups. The homogeneity test results of pre-test results showed the value of 0.268 . So, in pre-test, data are also homogeneous. The homogeneity of two group data variant necessary to the research conclusion drawing, then the calculation of the covariant analysis will produce accurate result.

\section{FINDINGS}

\section{Present science learning process}

The qualitative preliminary studies are conducted with the aim of obtaining preliminary data of classroom conditions related to the needs of learning media. The data of students' learning activities, potential and challenges faced, the availability and use of supporting schools facilities, and the students' academic achievements are collected in this preliminary study.

Based on the in-depth interviews results, the researcher assumes that the teachers still play in his comfortable zone. They teachers constantly employ the teacher-centered learning approach and only consider how learning can run well as usual. The lecturing, dictation and memorizing method are still mostly used in classroom. The reason of using those methods is the limitation of time related to the lot of number of task and material should be taught. This synthesis comes from several statements from teachers answering the question on what method did they use in class? And what is the reason? They think memorizing is still acceptable since we have many tasks to do. They also stated that have to teach 5 chapters in only 7 meetings, so they have to manage time slightly. Furthermore, they realize and have an intention to use modern learning method but then time allocation is their main obstacle to try to use those interactive methods.

The researchers also found that the supportive facilities provided by question of how did the authority support and facilitate their intention to try modern learning method? In fact, the facilities provided by the school and government authority are adequate to employ interactive learning media. Especially for primary school the existence of LCD projectors in all classroom and laptops for each teacher are categorized as good. However, it seems that the teachers have not been motivated and enthusiastic in utilizing the facilities in creating innovative learning processes. The lack of teachers' motivation, enthusiasm, and creativity in making learning media also effect this situation. 
Based on the observation results on learning activities in classroom in science subjects, the researcher found that the teacher still (a) features conventional lecturing methods and assisted with scheme and picture aids manually drawn on the white board and reading the module provided by school (rote learning). The challenges in this method are students' misinterpreting and lack of the Latin terms mastery. In addition, when the teacher try to explain by drawing on the white board, the students even let themselves behind the class joking and playing with their friends. Incidentally drawing in the white board to visualize the science materials is also takes time much while looking at picture on the book or module is occasionally drab. When the teacher is drawing, they are lost of control toward the students since no one pays attention on students' activities. The lag time while the teacher draws for long time and frequent will make students getting bored and lack of interest in learning activities. The use of those methods, finally, causes learning to be teacher-centered. As a result, the information is fully provided by teacher rather than discovered, students will only listen to and try to understand what the teacher conveyed and tend to be quiet and passive in learning group.

During the observation, the researcher also found that (b) learning process carried out is still meaningless. This can be along with the selected learning methods implemented in classroom where students are only received makeshift theories and props in understanding complex science theories and process in Latin terms. Students also failed to find the essence and need of science learning, felt confused, bored and less attracted in since the teachers are failed to connect the subject matter with real life so that. As the result, the student will intent to related the material by their basic knowledge and understanding they have before. This will come into a fallacy since the primary students, who in phase of concrete operational cognitive development will find a challenge to accept conceptual material without visualization.

The findings are identified as factor of several problems on students' outcomes such as motivation, concentration and understanding. (a) Students become less motivated when the rule of learning dominated by teachers and there is no innovation attracted to for a long-time learning. The use of the combination of interactive learning media and lecture method may result more interesting and motivated learning. Vice versa, if the lecture methods are used and combined with still picture drawn, the students were getting bored and feel indifferent in the classroom. (b) Regarding to the students' concentration, teacher should provide a dynamic activities and media during learning. This dynamic activity should appear along the classroom learning. When the teacher delivers in front of class, students become apathetic and busy with their friends, when the teacher draws scheme, students were playing and even running around the class. This classroom situation needs a limelight to get students' attention. A moving media, video or display will be helpful since the move and change will be easier noticed (eye-catching) by primary student rather than a static picture. The absence of laboratory equipment, concrete illustrations and visual media make students easier to disturb in doing learning and effect to concentration on lessons. (c) Students' less understanding on the teacher's explanation can be caused by the complex and conceptual characteristics of science. The many foreign terms and theories contained potentially make students confused and need deeper explanation. All those problems are drawn from the result of students' mid-term 
report which mostly are under the passing grade. The situation needs a combination of complex source to accommodate the students' variety of learning style. The combination of visual and audio can help them recognized the concept while understanding the process of science in the same time. Multimedia also that make students more aware of the lessons being taught and maximize the rule of teacher to only manage and facilitate learning. The classroom shifting rule will make the students learning independently discover more knowledge by their self-pace.

Regarding to availability of supporting facilities and infrastructure, generally the schools have enough facilities to support the implementation of interactive teaching aids. The existence of display projectors, computer and internet connection in every classroom provides broader potential alternative in creating and employing modern learning media. Related to the intention on implementing interactive media, some challenges are observed. The lack of competence, especially for senior teachers, in mastering information technology is a major challenge in the learning media use faced in classroom. The availability of ICT device has not been utilized by teacher optimally. It can be associated with the readiness to use technology in the classroom. Moreover, the senior teacher's mindset is inadequate in using the lecture method rather than to use interactive media. Finally, the researcher found that all those student learning problems effected the students' achievements. The students' cognitive achievements are not accordance with the target of minimum passing grade. From documentary observation, in the science subjects and the nature of light focus material, only 30 from all respondents reached passing grade score. The existence of school facilities should be a support to breakout using innovative and interactive learning media to improve learning achievements.

The finding of need analysis in previous step became the basic capital to prepare this product. Based on the results of the need analysis, the researchers collect the materials used for the media development. Materials for product content are compiled from learning materials, lesson plans made by teachers and syllabus. The compilation aims to produce a feasible and accurate product in accordance with the lesson plans and learning objectives. The researchers choose the materials of "The Properties of Light" as the video content since the material is prospective material faced by students for three meetings ahead. The content, media script, as well as images, background music and supporting animations used to compile animated learning motion graphic media are validated through focus group discussion (FGD) with teachers and school authority. Teachers and school authorities involved in this FGD gave their advice and point of view based on their need and experiences during classroom learning. This product preparation step produced an initial product of motion graphic video.

The initial video developed by the researcher are packaged in an interactive compact disk (CD) learning containing four division, they are Learning Objective, Materials, Exercise and Help section. In Learning Objective section, students can take a look on the basic competence should be achieved and the step of learning. So, the teacher no need to explain what students will study. In Material section, the students will see some videos created by related to the light definition, the properties of light and the use of 
light in daily life. In Exercise section, students will face two form of question to test their mastery. Multiple choice and matching test are selected based on the suitable characteristics of primary school learners. Then, in Help section, it briefly shows the contents of the menus and buttons in disk. It functioned to help students to understand use of menu or section. It is provided to guide the user to follow the desired menu.



Figure 1

Main Menu

\section{Standar Kompetensi \& Kompetensi Dasar}

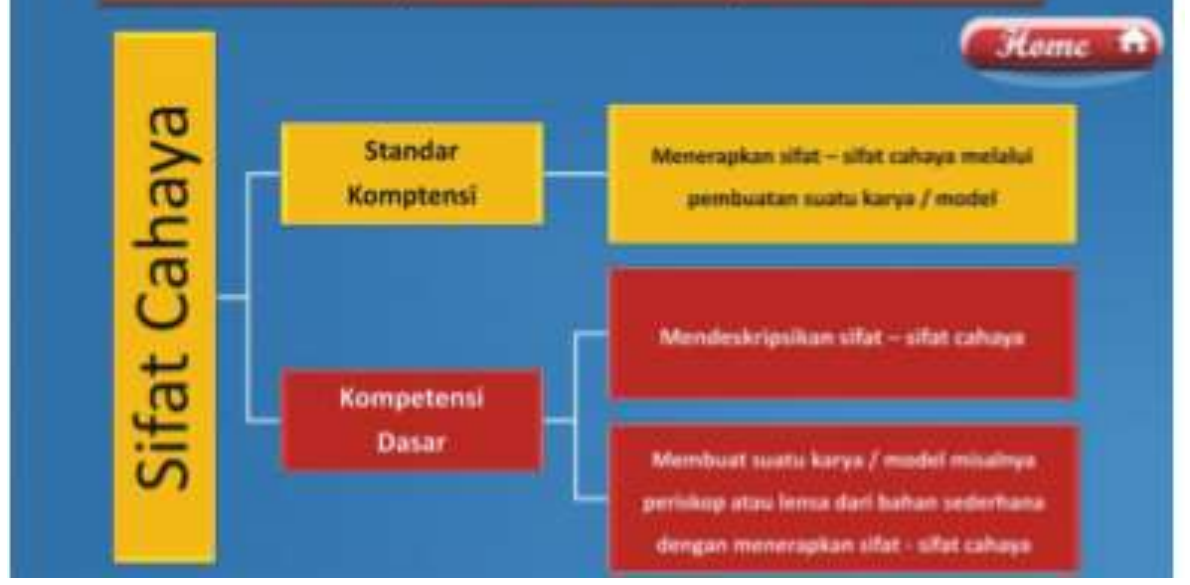

Figure 2

Learning Objectives Section 


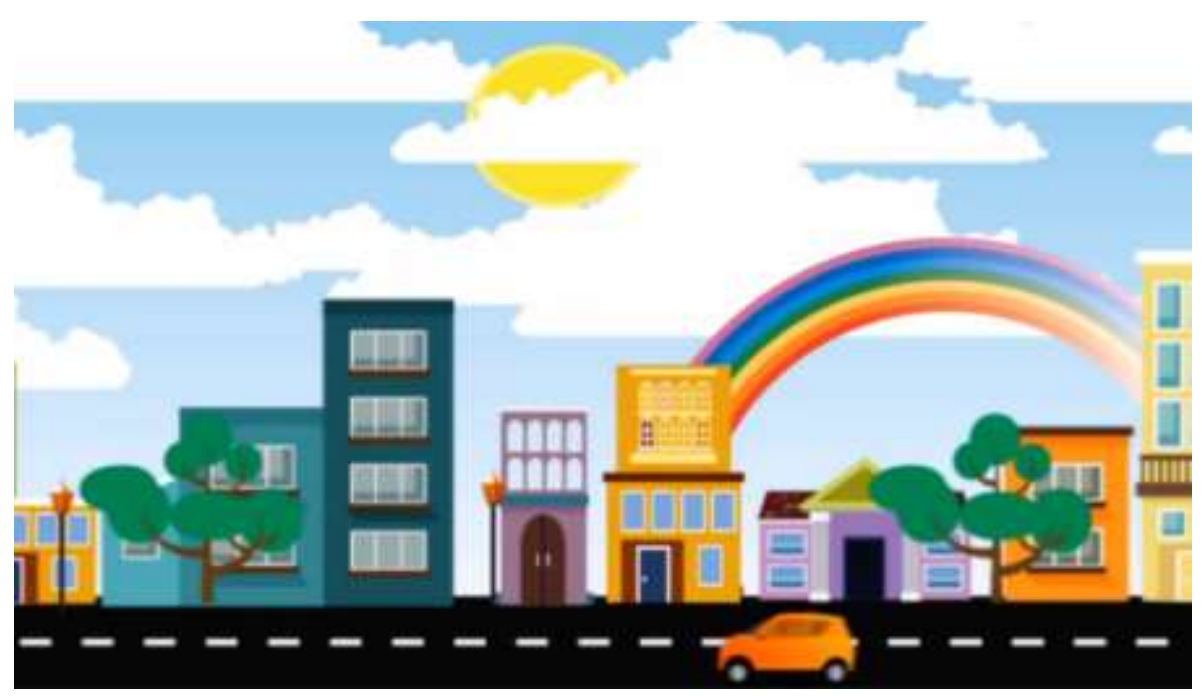

Figure 3

Description About Light

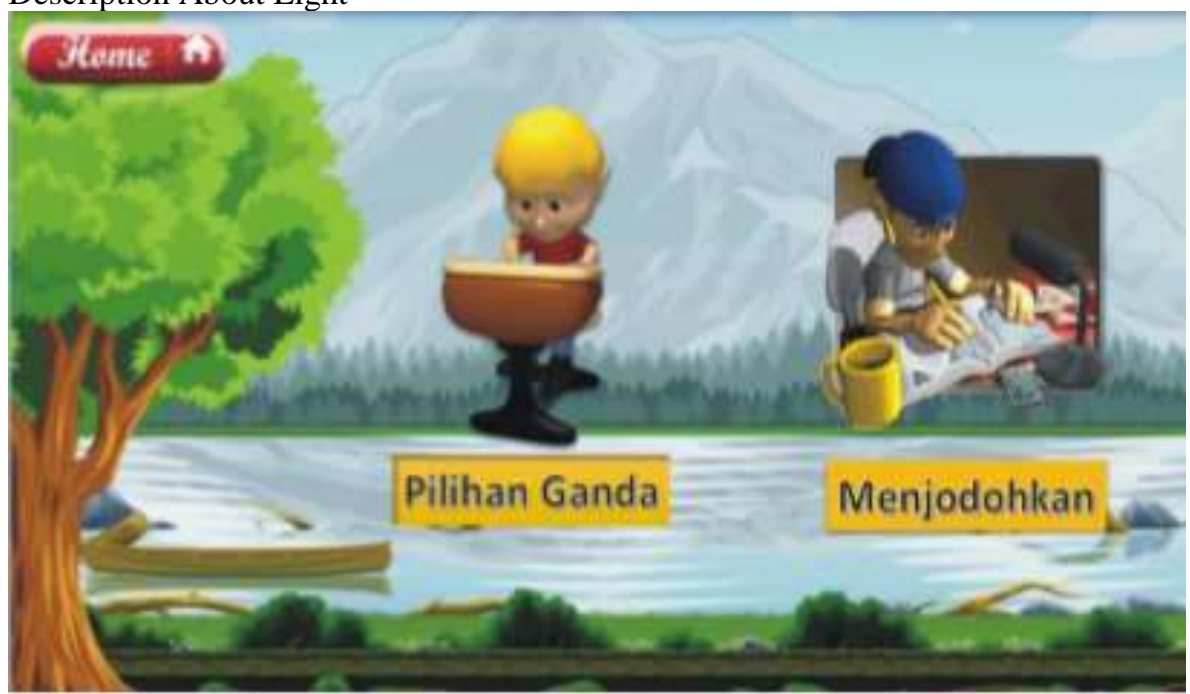

Figure 4

Exercise Section 


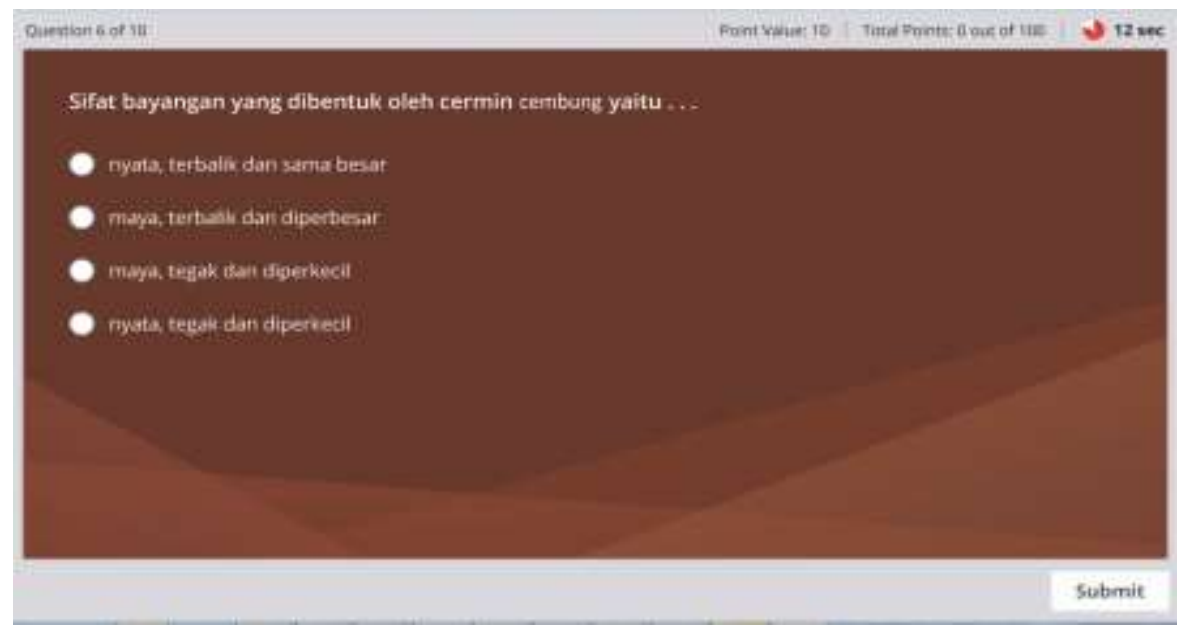

Figure 5

Multiple Choice Test

\section{Bantuan}

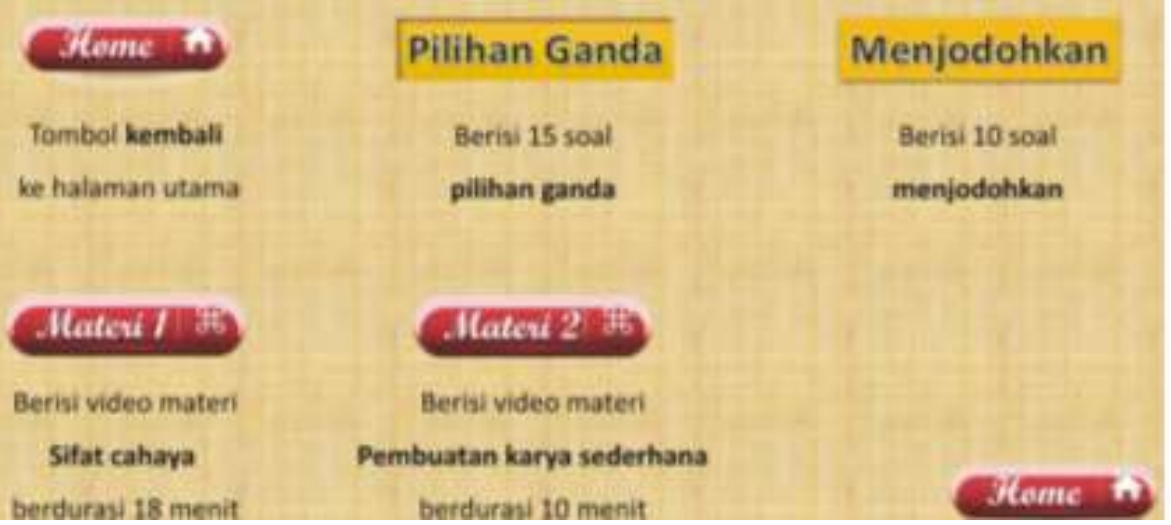

Figure 6

Help Section

Furthermore, the media has validated by prospective user and experts to examine the feasibility of product. User validated the feasibility on visual, material and language aspects. Thus, the media experts validated on learning goals, content quality, linguistic and video display as well as the ease of video aspects. The materials expert also stated that the media is feasible, well developed and ready to practically use in aspect of language, presentation and facilitation and video display. The result concluded that the initial motion graphic video media gets a feasible and good category to proceed to the 
practical use. Researcher tried to examine the feasibility of instrument and measure the cognitive achievements of participants before going through experimental test.

\section{Motion graphic animation effectiveness for learning in primary school}

To examine the effectiveness of motion graphic video media, the researcher conducted an experimental study. This quasi experimental study involved total of 54 students from two different school as experimental and control group. The researcher selected the class randomly and avoided students who have been involved in previous trials. The experimental group was carried out in 2 meetings with approximately 45 minutes for each meeting. The motion graphic video is played in front of the class for about 15 minutes per one video. After watching the video, teacher split the class into five groups and give a problem to be discussed by students in groups. After discussion, students were given an opportunity to present and share their finding in front of the class. The sharing information and clarification will be closed by teacher with a conclusion and followed by a test. The data in this study were obtained from pre-test and post-test score of the experimental group and the control group. The sample used to follow the test was 27 students for each group with thirty multiple choice questions are distributed to them.

Experimental Group Pre-test Data

The results of the pre-test scores of the experimental group students can be seen in the table below:

Table 3

Pre-test Experimental Group Score

\begin{tabular}{llll}
\hline Mean & Median & Mode & Standard Deviation \\
\hline 50.59 & 50.00 & 40.00 & 9.951 \\
\hline
\end{tabular}

Table 3 above indicates that the mean score of experimental group pre-test is 50.59. This shows that the average experimental class students did not meet the minimum criteria of passing grade standard. Thus, the median, the mode and the standard deviation are 50.00, 40.00 and 9.951 respectively. A treatment needs to be taken to increases the students' achievement and exceeds the specified passing grade standard..

\section{Control Group Pre-test Data}

The control group has also taken the pre-test. They are taught by using existing conventional methods and media. The result of the pre-test scores of the control group is drawn in the table below:

Table 4

Pre-test Control Group Score

\begin{tabular}{llll}
\hline Mean & Median & Mode & Standard Deviation \\
\hline 48.28 & 47.00 & 40.00 & 8.071 \\
\hline
\end{tabular}

The table 4 above showed that the mean score of the control group pre-test is 48.28. Similar to the experimental group, the mean score control group also did not meet the minimum passing grade standard criteria. Thus, the median, the mode, and the standard 
deviation is $47.00,40.00$ and 8.017 respectively. Moreover, this result indicate that those two groups, have same characteristics before the treatment conducted.

\section{Experimental Group Post-test Data}

The experimental group takes the post-test after the using the proposing alternative media in learning to measure the students' achievement after treatment. The post-test results of the experimental group can be seen in the table below:

Table 5

Prost-test Experimental Group Score

\begin{tabular}{llll}
\hline Mean & Median & Mode & Standard Deviation \\
\hline 71.72 & 70.00 & 70.00 & 7.120 \\
\hline
\end{tabular}

The table 5 showed that the mean score in the experimental group post-test is 71.72 . This means that the average score of experimental class after treatment has met the criteria of passing grade. Thus, the median, the mode and the standard deviation is $70.00,70.00$ and 7.120 respectively. The result showed that there is improvement compare to the pre-test score. There is 21.39 points increasing score in average.

\section{Control Group Post-test Data}

Even though did not give the treatment, the control group also performed post-test to see weather learning using conventional learning methods also have impact to the achievements. The results of the post-test scores of the control group can be seen in the table below:

Table 6

Post-test Control Group Score

\begin{tabular}{llll}
\hline Mean & Median & Mode & Standard Deviation \\
\hline 65.67 & 63.00 & 60.00 & 6.703 \\
\hline
\end{tabular}

The table 6 shows that the mean score of the control group post-test is 65.67. This means that the average score of control class failed to meet the criteria of minimum passing grade standard. Thus, the median, the mode and the standard deviation is 63.00 , 60.00 and 6.703 respectively. The result showed that there is improvement compare to the pre-test score. There is 17.13 points increasing score in average

\section{Analysis T- Test}

T-Test is test is an analytical to technique measure the difference between mean of two groups of data. In this study the researcher used independent sample t-test in each group both pre-test and post-test to avoid effect of uncontrolled independent variables before the treatment. T-test is used to examine the significant difference between control and experimental group score. Independent sample t-test is selected since the sources of data are from two different groups. The groups are assumed as having significant difference when the sig. value is greater than 0.005 and t-obtained is greater than t-table. 
The first t-test analysis is to analyze the significant different between pre-test score. The test is executed to analyze the condition of two groups before treatment of motion graphic video media use. This study assumed that the pre-test score has no significant different

Table 7

Independent Samples T-Test Result of Pre-Test Scores

\begin{tabular}{lllll}
\hline T-test for Equality of Means & & & \\
\hline Cognitive Learning & df & Sig. (2-tailed) & Mean Difference t-table \\
\hline
\end{tabular}

Learning

2.006

Achievements (pre-test)

Based on the table 7 above, it can be seen that the significance value of two tailed is 0.347 . By the df of 52 the analysis gained the t-obtained score of 0.949 and t-table of 2.006. The sig. value of 2-tailed is greater than 0.005 . This indicates that the pre-test score of the control and experimental groups have no significant difference. It is assumed that the two groups have the same cognitive level before the treatment. Even though there is a mean difference of 2.307, the groups are assumed as having the same cognitive achievements before the use of treatment of using media motion graphics animation. The analysis showed that the groups are eligible to be compared after the using of media as treatment. The assumption of this result is fulfilled where there is no uncontrolled variables will affect the effectiveness test of media.

Table 12

Independent Samples T-Test Result of Post-Test

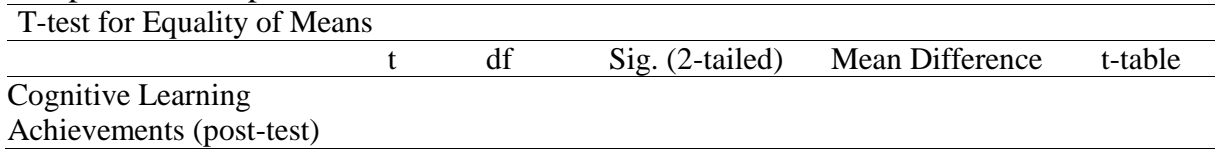

The table 12 above revealed t-obtained of 3.196 with a sig. value of 0.002 at 0.05 alpha level. On this basis, the significant value 0.002 is lower than 0.05 alpha level $(0.002<$ 0.05). Thus, there is a significant effect of treatment on students' learning achievement existed between the experimental and control group in post test. So, it can be concluded that at the $95 \%$ confidence level, there is the effect of using motion graphic media on the students' science learning achievement.

\section{DISCUSSION}

This study finds the need for interactive learning media as alternative to facilitate student in science learning. The presence of several learning problems and potentials drive this study to prove empirically the effectiveness of motion graphic video on students learning achievement in science as an alternative solution. In the qualitative part of this study, the researcher tries to explore specific problem that can be solved by the help of technology-based media learning, then propose an alternative of motion graphic video to improve science learning achievement.

In the quantitative part of this study, the researcher followed up the presence of need of learning media and the proposed developed video media by an effectiveness test through 
experimental study. At the end of the study, there is a significant difference in cognitive learning achievement between experimental and control classes after treatment of using motion graphic video media. The material used and the process of development in this study has been explain in the previous study (Hapsari et al., 2019).

After the experimental treatment of using motion graphic video, the average score of the experimental and control group in post-test are 71.72 and 65.67 respectively. There is 6.05 points gap between the two groups in post-test. The group also performed an improvement in learning achievement after treatment. The score improvement of the two groups from pre-test results to post-test results was obtained by the experimental group. The improvement of the experimental group score was 21.11 and the improvement of the control group was 17.40 respectively. Those improvements come from the effect of changing learning situation. Thus, the experimental class performed better learning achievement results compared to the control class that use existing conventional methods and media on science subjects of fifth grade of primary school. Even though performed an improvement, the improvement of the control class achievement is out of the discussion.

To explain the improvements in term of the effectiveness, the analysis of independent sample t-test is conducted by comparing post-test mean scores of control and experimental groups. After hypothesis testing, the result shows that there is a significant difference in cognitive learning achievement between the experimental and control class. Then, the difference can explain that motion graphic video media is more effective than existing conventional learning media. So, it briefly concluded that learning by using motion graphic animation video media is empirically effective to improve science learning achievement (Hapsari et al., 2019). This result is also supported the existing literature that the appropriate media utilization will have a critical impact on the classroom learning outcomes. The animation video used should facilitate the learners' characteristics (Pricahyo, Akhyar, \& Suharno, 2018). The animations media meet the young learners' characteristics of actively socialize as well as concretely think. Therefore, interactive video media made students easier to understand the material delivered by teachers.

Compared to the use still picture learning media, the motion graphic video is substantially more effective to explain the conceptual and abstract materials. It was assumed from the features of media developed that contain an attractive package, basic competence explanation, interactive animated videos and exercise section make students to pay more attention and unconsciously learn while watching (Naylor \& Keogh, 2013). The features of moving animation easily get the students' attention. Students become more interested because the moving animation video presented made learning interactive and joyful as well as supported by a student-centered learning method in form of simple directed discussion and presentation. In addition, students' thinking abilities are driven and guided to the material presented in the video because the close relation between content presented in the motion graphic animation video and their daily lives situation. 
The result of this study is in line and support the research results that has been stated above mentioning the effectiveness video on conceptual material subject (Berney \& Bétrancourt 2016). In cognitive activities and mastering conceptual materials, the motion media is beneficial. The result highly implicates the strong relationship between the use of video animation and science learning achievements. As the study of Khalid et al. (2010) that stated the animation or cartoon use made science learning more attractive and joyful. In the study, the researchers observed that physics learning, as the one of science branch learning, is effectively improved by the attractive animation video. The interactive and colorful display and exercise provided in animation video affected the students' activeness during learning. The investigation on other science branches such as chemistry and biology should be suggested to be examined in the future.

\section{CONCLUSSION}

This research investigated the motion graphics video media effectiveness that has been developed for solving science learning problem in primary school. The motion graphics is proposed to be alternative based on the existing problem found in the qualitative stage. The results of this study reveal that the use motion graphic video media have a significant impact on students' cognitive achievement. The features of proposing media effectively influenced the experimental group learning achievement. The interactive feature of motion graphic meets the students' need of active learning situation. By integrating motion graphic video media with student-centered method in their classroom, the active learning setting is easier to create. The students of experimental group are observed to be more active and concentrated in the process of learning. The media is also proven to increase students' understanding of the factual and conceptual material. Students can simply recognize and develop further their new knowledge maximally since the material is closely linked to their basic knowledge and daily life. This is evidenced that the motion graphic video media can be prospective alternative solution to the limitations of the laboratory equipments, printed media and other visualizations media in learning science for primary students. The combination studentcentered activity and motion graphic media can promote active learning for young learner.

\section{SUGGESTION}

Motion graphic video media can be a reserve completion to the limitations of laboratory equipments, conventional printed book, picture and other visualizations media to teach factual and conceptual knowledge. This is proven that the experimental group which using the interactive motion graphic animation video performed better cognitive achievement in science learning compared to control group that using the still picture media. They use of interactive media for young learners should be continuously promoted so that the students can massively benefit and feel the improvement. Although the motion graphic animation video use has a positive effect, it should be considered to still combine with the appropriate teaching method. The use of interactive media should be based on the factual students' learning needs and accommodate their characteristics and learning style. Further development, modification and creation also could be executed in the future to enrich the potential of use. 


\section{LIMITATION}

This research only investigates the effect of motion graphic animation video in cognitive achievement aspect. Another aspect of learning outcome such as attitude, skill, and other attributes which is ruled out in this research can be potential aspect to be investigated in the future research The use of motion graphic media content in this study is designed specifically for specific subject and learner level that still can be enlarged in further research. The different and larger aspect such as side effect, user satisfaction, internal and external acceptance and other challenges and potential in investigating the motion graphic animation video effectiveness still may be deeply examined in other context, scope, and aspect as well as setting of participant. The different approach and point of view is also potentially provided different result to the present study.

\section{REFERENCES}

Adilah, N. (2017). The difference between learning outcomes of science taught by mind map and didactic method. Indonesian Journal of Primary Education, 1(1), 98-103. doi:https://doi.org/10.17509/ijpe.v1i1.7521

Akamca, G. Ö., Ellez, A. M., \& Hamurcu, H. (2009). Effects of computer aided concept cartoons on learning outcomes. World Conference on Educational Sciences 2009. 1, pp. 296-301. Nicosia: Elsevier. doi:https://doi.org/10.1016/j.sbspro.2009.01.054

Anikina, O. V., \& Yakimenko, E. V. (2015). Edutainment as a Modern Technology of Education. Procedia - Social and Behavioral Science, 166, 475-479. doi:https://doi.org/10.1016/j.sbspro.2014.12.558

Asrowi, Hadaya, A., \& Hanif, M. (2019). The Impact of Using the Interactive E-Book on Students' Learning Outcomes. International Journal of Instruction, 12(2), 709-722. doi:10.29333/iji.2019.12245a

Assar, S. (2015). Information and communication technology in education. In J. D. Wright, International Encyclopedia of the Social \& Behavioral Sciences (Second Edition) (pp. 66-71). New York: Elsevier Ltd. doi:10.1016/B978-0-08-097086-8.921044

Bagatarhan, T., \& Siyez, D. M. (2017). Programs for preventing Internet addiction during adolescence: A systematic review. Addicta: The Turkish Journal on Addictions, 4(2), 243-265. doi:10.15805/addicta.2017.4.2.0015

Berney, S., \& Bétrancourt, M. (2016). Does animation enchance learning ? A Metaanalysis. Computers \& Education, 101, 150-167. doi:https://doi.org/10.1016/j.compedu.2016.06.005

Creswell, J. W., \& Clark, V. L. (2011). Designing and Conducting Mixed Methods Research (Second Edition). Los Angeles: SAGE Publications.

Gellerstedt, M., Babaheidari, S. M., \& Svensson, L. (2018). A first step towards a model for teachers' adoption of ICT pedagogy in schools. Heliyon, 1-17. doi:https://doi.org/10.1016/j.heliyon.2018.e00786 
Gurbuzturk, O. (2018). Investigation of Elementary EducationStudents' Attitudes towards the Use of Smart Boards. International Electronic Journal of Elementary Education, 11(1), 55-61. doi:10.26822/iejee.2018143961

Hapsari, A. S., Hanif, M., Gunarhadi, \& Roemintoyo. (2019). Motion Graphic Animation Videos to Improve the Learning Outcomes of Elementary School Students. European Journal of Educational Research, 8(4), 1245-1255. doi:10.12973/eujer.8.4.1245

Hlasna, P., Klimova, B., \& Poulova, P. (2017). Use of Information and Communication Technologies in Primary Education -A Case Study of the Czech Republic. International Electronic Journal of Elementary Education, 9(3), 681-692. Retrieved from https://www.iejee.com/index.php/IEJEE/article/view/183/179

Huda, M., Jasmi, K. A., Mustari, M. I., Basiron, B., Hehsan, A., Shahrill, M., \& Gassama, S. K. (2017). Empowering Children with Adaptive Technology Skills: Careful Engagement in the Digital Information Age. International Electronic Journal of Elementary Education, 9(3), 693-708. Retrieved from https://www.iejee.com/index.php/IEJEE/article/view/184/180

Ignatyeva, I. (2015). The trend of technologisation of modern education (the use of humanitarian technologies). Procedia-Social Behavioral Sciences, 214, 606-613. doi: 10.1016/j.sbspro.2015.11.766

Kayimbaşioğlu, D., Oktekin, B., \& Haci, H. (2016). Integration of Gamification Technology in Education. 12th International Conference on Application of Fuzzy Systems and Soft Computing. 102, pp. 668-676. Vienna: Elsevier. doi:https://doi.org/10.1016/j.procs.2016.09.460

Khalid, H., Meerah, T. S., \& Halim, L. (2010). Teachers' Perception towards Usage of Cartoon in Teaching and Learning Physics. International Conference on Learner Diversity 2010. 7, pp. 538-545. Bangi: Elsevier. doi:https://doi.org/10.1016/j.sbspro.2010.10.072

Naylor, S., \& Keogh, B. (2013). Concept Cartoons: What Have We Learnt? Journal of Turkish Science Education, 10(1 ), 3-11.

Pricahyo, E. W., Akhyar, M., \& Suharno. (2018). Development of motion graphic animation video in elementary school. Advances in Social Science, Education and Humanities Research, 165, 121-125. doi:10.2991/iccsr-18.2018.27

Shaban, A. E., \& Egbert, J. (2018). Diffusing education technology: A model for language teacher professional development in CALL. System, 78, 234-244. doi:https://doi.org/10.1016/j.system.2018.09.002

Ucus, S. (2015). Elementary School Teachers' Views on Game-based Learning as a Teaching Method. 5th World Conference on Learning, Teaching and Educational Leadership. 186, pp. 401-409. Prague: Elsevier. doi:https://doi.org/10.1016/j.sbspro.2015.04.216 
Yakovleva, Y. V., \& Goltsova, N. V. (2016). Information and Communication Technologies as a Means of Developing Pupils' Learning Motivation in Elementary School. Annual International Scientific Conference Early Childhood Care and Education. 233, pp. 428-432. Moscow: Elsevier. doi:https://doi.org/10.1016/j.sbspro.2016.10.179 